\title{
1 Influence of geocell reinforcement on uplift response of belled piles
}

2

3 S.N. Moghaddas Tafreshi ${ }^{1, *}$ (Corresponding Author), S. Javadi², A.R. Dawson ${ }^{3}$

$4 \quad 1,{ }^{*}$ Corresponding Author. Department of Civil Engineering, K.N. Toosi University of Technology, Valiasr St., Mirdamad Cr., Tehran,

$5 \quad$ Iran. Tel: +982188779473; Fax: +982188779476; E-mail address: nas moghaddas@kntu.ac.ir

$6{ }^{2}$ Department of Civil Engineering, K.N. Toosi University of Technology, Valiasr St., Mirdamad Cr., Tehran, Iran. Tel: +982188779473;

7 Fax: +982188779476; E-mail address: rfsj_ce@yahoo.com

$8{ }^{3}$ Nottingham Transportation Engineering Centre, University of Nottingham, Nottingham, UK. Tel: +441159513902; Fax:

$9 \quad+441159513909 ;$; E-mail address: andrew.dawson@nottingham.ac.uk

10

11 Abstract: Piles are frequently used to transfer the heavy compressive loads to strong soil layers located in the depth 12 of bed. In addition, such piles may be subjected to combination of repeated compressive and tensile loads due to 13 earthquake, wind, etc. This paper describes a series of laboratory model tests, at unit gravity, performed on belled pile, 14 embedded in unreinforced and geocell reinforced beds. The tests performed to evaluate the beneficial effect of geocell in 15 decreasing the downward and upward displacements and performance improvement of the uplift response of belled pile 16 under repeated compressive and tensile loads. Pile displacements due to fifty load repetitions were recorded. The 17 influence of the height of geocell above the bell of pile, an additional geocell layer at the base of belled pile, and the 18 number of load cycles on pile displacements were investigated. The test results show that the geocell reinforcement 19 reduces the magnitude of the final upward displacement. It also acts as a displacement retardant, and changes the 20 behaviour of belled pile from unstable response condition due to excessive upward pile displacement in unreinforced bed 21 to approximately steady response condition. Therefore, the geocell reinforcement permits higher tensile loads or increased cycling. The efficiency of reinforcement in reducing the maximum upward displacement of the pile (i.e., pullout resistance) was increased by increasing the height of geocell above the bell of the pile. Furthermore, the comparison showed that a specific improvement in upward and downward displacement and the stability against uplift can be achieved using an additional geocell layer at the base. The geocell reinforcement may reduce the required length of pile shaft, consequently reducing required excavation, backfill and pile's material. Simple dimensional analysis showed the need for an increased stiffness of the geosynthetic components in order to match prototype-scale performance similitude.

Keywords: Uplift response; belled pile; geocell layer; upward and downward displacements, compressive and tensile loads. 
1

2

3

4

5

6

\section{Introduction}

Footings require the special attention due to different types of acting loads. Nowadays, more ambitious structures transmit not only large compressive forces but also considerable amount of tensile forces, to their foundations. The combination of compressive downward load and tensile upward load can play a destructive role and may lead to an uplift load on the structures. Typical on-shore and off-shore structures like television and transmission towers, tension cables for suspension bridges, tall chimneys, marine structures, etc., may be subjected to uplift forces. Among them, downward static loads such as dead load of structure, and upward/downward dynamic loads like loads due to earthquake, wind, and also cyclic forces from waves are some example forces with high possibility to occur in ordinary structures which their footings may be alternatively subjected to the large pullout forces. Conventional foundations are unable to take this type of loading, and soil anchoring systems require resisting the uplift forces. They hold down the structure when the uplift load is greater than the self weight of the structure, allowing the transmission of the pullout load to soil bed at a greater area and away from the structure.

Over the past few decades, in order to resist uplift tensile forces by providing passive resistance, a wide variety of foundation anchor systems such as anchor plate, anchor pile (i.e., belled pile) and pier, pedestal, pyramid, grillage, helical anchor, grouted anchor and suction anchor have been developed. Thus a relatively extensive research has been conducted on the uplift of anchors and anchor piles in unreinforced soil (e.g., Das, 1983; Tagaya and Scott, 1988; Dickin and Leung, 1990; Hanna and Ghaly, 1994; Ilamparuthi et al., 2002; Merifield and sloan, 2006; Sakai and Tanaka, 2007; Song et al., 2008; Kouzer and Jyant, 2009; Khatri and Kumar, 2009; Deskmukh et al., 2010; Horpibulsuk and Niramitkorburee, 2010; Honda et al., 2011).

Although, geosynthetic materials have been increasingly used in geotechnical engineering applications for different purposes e.g., stable embankments over soft soil, road construction layers, construction of footing (e.g., Moghaddas Tafreshi and Khalaj, 2008; Ling and Liu, 2009; Madhavi Latha and Somwanshi, 2009; Choudhary et al., 2010; Lovisa et al., 2010; Moghaddas Tafreshi et al., 2011; El Sawwaf and Nazir, 2012; Ahmadi and Hajialilue-Bonab, 2012; Leshchinsky and Ling, 2013; Tanyu et al., 2013; Yang et al., 2013), but relatively little attention has been paid to the response of anchors, anchor/belled piles in reinforced soil subjected to uplift load (Ilamparuthi and Dickin 2001a,b; EL Sawwaf and Nazir 2006; Ghosh and Bera, 2010; Consoli et al., 2012). Ilamparuthi and Dickin (2001a) investigated the influence of geogrid reinforcement on the uplift performance of small scale belled piles or piers embedded in sand. They reported that pullout resistance increases with the diameter of the geogrid cell, sand density, pile bell diameter, and embedment depth. Ghosh and Bera 
1 (2010) presented the results of experimental investigation on the effect of geotextile ties on uplift capacity of

2 anchors/enlarged pile base embedded in sand. They indicated that the uplift capacity of the anchor increases

3 with an increase in the ratio of embedment depth to base diameter, and with an increase in the number of geotextile layers. The optimum number of the geotextile layers of ties was found to be 2 . Consoli et al.

5 (2012) investigated the effect of polypropylene fibers on the uplift behavior of model footings embedded in sand. They reported that the uplift capacity increased considerably with insertion of fibers in the sand backfill

7 for all embedment depths.

8 The previous studies on the pullout load-displacement behaviour of anchors and anchor piles were 9 concerned about the case of unreinforced foundation, and reinforced foundation with planar reinforcement 10 (e.g., geotextile and geogrid reinforcement) under static uplift loads. Therefore, the above mentioned 11 literature indicates that there is a major lack of studies about the behaviour of anchors and anchor piles subjected to the alternating pullout forces (the term "repeated loads" may be used in this paper for the specific alternating pullout forces) when supported in geocell reinforced soil.

14 In the research described here, and in order to develop a better understanding of the behaviour of belled 15 piles, under the alternating pullout forces (i.e., a combination of static and repeated loads), embedded in geocell-reinforced soil, a series of different laboratory, pilot-scale tests were performed. The overall goal was to demonstrate the benefits of geocell, with the detailed objective of this study being to compare the performance of geocell reinforced and unreinforced systems on the uplift response of a single belled pile. The reason for selecting geocell reinforcement is that Moghaddas Tafreshi and Dawson (2010a;b), in their studies on the static and dynamic responses of shallow footings supported on geocell and geotextile-reinforced sand beds at model scale tests, indicated that the geocell reinforcement system is both stiffer and stronger than the system with planar reinforcement.

\section{2. Problem statements and belled pile construction}

Belled piles are under-reamed straight shaft piles and are often required for engineered substructure design. Belled piles can be an economical way to enlarge the end area of a pile (bottom). The cone-shape enlargement of pile bottoms will result in substantially higher bearing capacity and particularly suited to ground conditions where a strong stratum is overlain by soft strata in which pile shaft friction will be small or even negative. Using belled piles can usually reduce costs as they normally are kept shorter than their straight shaft counterparts. This requires less material such as concrete and steel. On a typical pile diameter of 800 or $1200 \mathrm{~mm}$ bell sizes between 1500 and $3000 \mathrm{~mm}$ diameter are common. Construction of belled piles in 
1 unreinforced soils needs to employ the rotary excavation method to drill and to create an enlarged base

2 (under-ream) as a bell shape at the bottom, which increases the base bearing capacity of piles in competent

3 soil strata and increases the uplift load capacity. Belled piles or piers primarily rely for their anchorage capacity on the resistance of the soil in which they are embedded. The capacity of a buried anchor or belled pile essentially comprises the weight of soil within the failure zone above the bell, the frictional resistance along the failure surface and the self-weight of the foundation. In normal cases, the required uplift capacity of belled piles can be achieved by increasing the bell size, the depth of embedment and the density of the backfill, if possible.

The studies of researchers (e.g., Dash et al., 2007; Madhavi Latha and Rajagopal, 2007; Moghaddas Tafreshi and Dawson 2010a;b;2012, etc.) showed that geocell reinforcement, being an interconnected cage, appears to derive substantial anchorage from both sides of the loaded area due to the frictional and passive resistance developed at the soil-geocell interfaces. It seems that this action is similar to that of a beam or raft spreading the loading to remote positions. Therefore, the use of geocell reinforcement in the trench over and beneath the belled of pile (see section 6) could provide the potential to increase the tensile load capacity and the compressive bearing capacity, respectively, and consequently might limit deformation of the belled pile and ground surface deformation. Therefore, instead of increasing the bell size or the depth of embedment, the authors aimed to investigate the improvement effects of using geocell reinforcement on the uplift response of belled piles and to develop this concept for field construction.

Construction of belled piles in reinforced backfill follows a different procedure from that described above. In this case, the precast concrete or precast steel belled pile should be used and thus the practical depth is limited. It would be constructed specially to resist any uplifting force or overturning moment placed on a structure. Belled piles in reinforced backfills can be installed by excavating the ground to the required depth, placing the geocell layers and short precast belled pile and then backfilling with soil in compacted layers. It is similar to the installation of anchors used as supports for retaining structures that are installed in excavated trenches and connected to tie rods.

Fig. 1 shows the installation steps of this type of belled piles. The methodology of precast belled pile installation in geocell reinforced backfill is as follow: 
- installation of the bottom geocell layer and compaction soil inside the opening of geocell (Fig. 1b). If there is no possibility of the compression load exceeding the bearing capacity of the underlying stratum, this might be unnecessary;

- installation of the precast belled pile in the centre of the trench over the bottom geocell layer followed by soil compaction in layers around the bell of the pile (Fig. 1c);

- placement of the layer of geocell reinforcement above the bell of the pile, compaction of soil inside the geocell's openings followed by compaction of soil in layers around the shaft of pile to achieve the level of final soil surface (Fig. 1d)

\section{Goals}

The overall goal of the current study was to investigate the response of belled piles to compressive and tensile repeated loadings, particularly to demonstrate the benefits of using geocell layers above and beneath the bell of the pile. Thus, a total of 14 independent static loads and repeated load tests (plus 10 repeated tests) on a belled pile model supported on unreinforced sand and reinforced sand with geocell was performed to:

a) evaluate the performance of geocell reinforced system above the bell of pile to improve the uplift response (i.e., to decrease the upward displacement of the belled pile) as compared with unreinforced system,

b) investigate the influence of height of geocell layer above the belled pile on pile displacement,

c) demonstrate the benefits of an additional geocell layer at the base of the belled pile on uplift response of the belled pile.

It should be noted that one type of geocell, one size of shaft pile diameter, one size of bell diameter, one size of embedment depth of pile, and one type of soil were used. The results should, therefore, have direct applicability, qualitatively, to the applications envisaged and could have wider application for more general belled pile use, but will need scaling and adjusting for different soil properties and different geosynthetic properties in such cases.

\section{Model Tests}

A physical model was tested to provide relatively close-to realistic test conditions. The general view of the physical test setup comprising a testing tank, loading system and data measurement system, is shown in Fig. 2 .

\subsection{Testing tank}


The test tank is a rigid box with the dimensions of $1000 \mathrm{~mm} \times 1000 \mathrm{~mm}$ in plan view, and $1000 \mathrm{~mm}$ height. The back and side faces of the tank consist of smooth MDF $20 \mathrm{~mm}$ thick sheets. To allow visual 3 observations of the foundation bed, as well as photo scanning, the front face of the tank is made of $20 \mathrm{~mm}$ thick Plexiglas. To prevent undesirable movement of the four sides of the tank, the rigidity of the tank has been guaranteed by using stiff steel section (U-100) on four sides of the tank. According to some preliminary test results (not further reported here), under a maximum compressive loading stress of $1000 \mathrm{kPa}$ on the belled pile model, the measured deflections of the sides of the tank were very small, demonstrating that they would be negligible at the stress levels applied in the main test program.

Because the width and depth of the test tank were about seven times bigger than the diameter of the enlarged base of the pile $(D=150 \mathrm{~mm})$, the boundary effect on the test results was considered insignificant. During the pullout tests on the belled pile model, it was observed that the soil surface bulging around the pile extended less than 2.5-3 times of the bell diameter, indicating that the boundary effect of the box walls on the test results was likely insignificant.

\subsection{Loading system}

The loading system includes a loading frame, a hydraulic cylinder, and a controlling unit. The loading frame consists of two stiff and heavy steel columns and a horizontal beam that supports the hydraulic actuator. The actuator may produce monotonic or repeated loads in both compressive and tensile directions with a maximum capacity of $20 \mathrm{kN}$.

\subsection{Data measurement system}

The data measurement system was developed to read and record both load and settlement automatically. An S-shaped load cell with the accuracy of $\pm 0.01 \%$ and a full-scale capacity of $15 \mathrm{kN}$ was placed between the loading shaft and the footing to precisely measure the applied load. The average settlement of the footing was monitored during the loading, unloading and reloading by two linear variable differential transducers (LVDTs) with the accuracy of $0.01 \%$ of full range $(100 \mathrm{~mm})$, located on diametrically opposite edges of the footing. All of the devices were calibrated prior to each series of tests.

\section{Material properties}

\subsection{Soil}

The soil used is a relatively uniform silica sand of grain sizes between 0.85 and $2.18 \mathrm{~mm}$ and specific gravity of $2.68\left(G_{s}=2.68\right)$. The grain size distribution of this sand is also shown in Fig. 3. The properties of 
1 the sand, which is classified as SP in the unified soil classification system (ASTM D 2478), are given in

2 Table 1.

\section{$3 \quad$ 5.2. Geocell}

The geocell used in this study was fabricated from a type of a planar polymeric geotextile that was 5 thermo-welded to form a 'non-perforated geocell' (Fig. 4). This type of geocell reinforcement provides 6 confinement chambers, which prevent the lateral displacement of infill from spreading, and therefore 7 hindering displacement. Approprate tensile strength of both the weld and the geosynthetic are required to deliver a structure with high load-bearing capacity; otherwise rupture of the geocell-soil matrix could result (Moghaddas Tafreshi and Dawson, 2010a,b).

The ratio of the geocell pocket size $\left(d_{g}=50 \mathrm{~mm}\right)$ to diameter of circular bell of pile $(D=150 \mathrm{~mm})$ was kept constant, while the geocell was used at thicknesses $\left(H_{t}\right)$ of $25,50,75$, and $100 \mathrm{~mm}$ in this testing program. A change in $d_{g} / D$ might alter the results and could be considered as a limitation of the testing program. Fig. 4 shows an isometric view of the type of geocell used in the investigations. The engineering properties of the geotextile (and thus, of the geocell walls) are presented in Table 2. According to the manufacturer (Treff, 2011), the strength and stiffness of the geocell joint is higher than or similar to that of the geocell wall material (i.e. geotextile).

Note that the geometry and the properties of the geocell reinforcement and the size and the properties of the sand are selected to match the scale of the model.

\section{Test preparation and procedure}

The schematic layout of the geocell layers and belled pile model is shown in Fig. 5. To provide the backfill matrix, the soil was compacted into the testing tank to a known density. The compaction energy was produced by means of a hydraulic cylinder (using the same hydraulic cylinder as applied the load during each test). This applies a constant pressure on a stiff wooden plate $(990 \mathrm{~mm} \times 990 \mathrm{~mm}$ in plan view). Thus a $5 \mathrm{~mm}$ wide gap was provided on each side of the tank to prevent contact between the wooden plate and the sides of the tank. The applied stress and the number of the compaction repetitions for different thicknesses of soil layers and different thicknesses of geocell layers were manipulated so that the soil's relative density for both unreinforced and reinforced beds was kept at around $84 \%$, the same for all of the tests. This value for the 25 and $50 \mathrm{~mm}$ thickness of unreinforced layers was obtained by using a fixed pressure of $15 \mathrm{kPa}$ applied one 
1 of $\approx 84 \%$ was achieved by using a fixed pressure of $20 \mathrm{kPa}$ applied one, two, three and four times,

2 respectively. To ensure that the calibration system produces the correct relative density, the sand cone tests in

3 accordance with ASTM D1556-07 were conducted to measure the densities of compacted soil layers, and the density of the soil filled into the geocell pockets. The densities measured for several tests, revealed a close match between density values of the cone tests and required density values with maximum differences in results of around $1-2 \%$. This difference seems to be small for geotechnical applications.

The unreinforced soil beneath the belled pile (and the geocell reinforced layers beneath the base of the pile, Test Series 5 in Table 3) was compacted in $50 \mathrm{~mm}$ thick layers until the surface reached the level of the base of the belled pile (beneath the bell). In the tests with an additional geocell layer at the base of the belled pile, the layer of geocell reinforcement was placed above the last unreinforced layer, and thereafter the soil was compacted inside the opening of geocell. The base of the bell of the pile was made rough by covering it with epoxy glue and rolling it in sand. Then, the belled pile model was placed in the centre of the tank, on the compacted soil surface. Thereafter, the first layer of geocell reinforcement was placed above the bell of the pile. Cell pockets in the geocell were filled with soil to include $1 \mathrm{~cm}$ thickness of extra soil over the geocell, after which the compaction of both the soil inside the opening of geocell and unreinforced soil above the geocell-reinforced layer was continued until the desired level of the soil surface was achieved. The model belled pile consists of a $550 \mathrm{~mm}$ cylindrical shaft with a diameter of $40 \mathrm{~mm}$, and a $20 \mathrm{~mm}$ thick bell with a diameter of $150 \mathrm{~mm}$ which embedded in unreinforced and geocell reinforced bed at a constant depth of 450 mm (Fig. 5).

An indicator plate was placed at the top of the shaft pile to connect the LVDT as shown in Fig. 2 and Fig. 5. The load cell was placed on the loading shaft, via a hemi-spherical connection designed to maintain vertical loading alignment to record the applied loads. The LVDT was set on the indicator plate to record the displacement data and load cell was placed between the loading shaft and the pile head to record the applied loads.

\section{Test parameters and testing program}

The geometry of the test configurations for belled pile embedded in geocell reinforced soil considered in these investigations is shown in Fig.5. Also, the details of both the static and repeated load tests are given in Table 3. Test series 1, 2, and 3 were conducted on the unreinforced bed and geocell reinforced bed by varying the height of geocell layer above the bell of the pile (dimension $H_{t}$ ) in the cases of both static and repeated loadings. Test series 4 and 5 were conducted under repeated loads on the geocell reinforced by 
1 varying the height of geocell layer above the bell of pile (dimension $H_{t}$ ) with and without an additional 2 geocell layer beneath the bell base. Test series 5 investigated the effect of geocell layer placed at the bell base 3 on uplift response of the belled pile.

To achieve the maximum performance of geocell reinforcement, the width of the geocell layers 5 (dimension $b$ ) was conservatively selected five times the diameter of the bell of the pile $(5 \times 150=750 \mathrm{~mm})$.

6 Moghaddas Tafreshi and Dawson (2010a, 2012) and Dash et al. (2003), in their studies on footing supported 7 by geocell reinforcement, reported the maximum value of this parameter to be about 3.2 and 3.6 times the footing width/diameter, respectively. Therefore, the selected value of " $b=5 \mathrm{D}$ " seemed to be adequate and was

9 kept constant in the tests described in this study..

10 Many of the tests were repeated carefully, at least twice, to examine the performance of the apparatus, the 11 accuracy of the measurements, the repeatability of the system, the reliability of the results, and finally to verify the consistency of the test data. The results obtained showed a close match between results of repetitive tests, so that the maximum difference between the results was only about $6-8 \%$. This difference was considered small and was subsequently neglected. It demonstrated that the procedure and the technique adopted can produce repeatable tests within the bounds that could be expected from geotechnical testing apparatuses.

\section{8. The Pattern of the applied load}

In the case of the static tests (Test Series 1 and 2 in Table 3), the belled pile was subjected monotonically to a tensile load at a rate of $1.0 \mathrm{kPa}$ per second until failure was reached. In the absence of a clear-cut failure, the pile was loaded until an approximately constant value of applied stress was achieved. In the case of the cyclic tests, the typical time history of applied alternative loads on the belled pile is as shown in Fig. 6. As it could be observed, the belled pile is subjected to a pre-specified static load of intensity, $q_{\text {stal }}=+350 \mathrm{kPa}$, applied at a rate of $1.0 \mathrm{kPa}$ per second. Then, a repeated load having an amplitude of $q_{c}=+800 \mathrm{kPa}$ in compressive (downward load) and an amplitude of $q_{t}=-100 \mathrm{kPa}$ in tension (upward load) is superimposed on the static load. Before applying the repeated compressive and tensile loads, the static load is kept constant until no further downward displacement occurs, or until the rate of displacement becomes negligible. During the tests, the static load is permanently applied on the footing while the compressive load is returned to zero and thereafter is changed to a tensile force at the end of each cycle. Downward and upward displacements of 
1 cycle/sec) was recorded. The intensity of compressive and tensile load is defined as P/A, which P and A are applied load and cross section of bell of pile, respectively.

In the practical design of foundations subjected to uplift loads, alternative load in both compressive and tensile directions are often of more importance than static uplift loads. Compressive and tensile alternative loadings are superimposed on the static load, which represents the dead and live loads of the structure and foundation. The repeated loadings pattern shown in Fig. 6, are selected to simulate the combination of static load and alternative loads likely to be experienced in many earthquakes, or due to the loadings of wind and waves on foundations.

\section{Results and discussions}

In this section, a brief summary of the results of the tests on the laboratory model is presented with a discussion highlighting the effects of the different parameters. The presentation of all of the figures makes the paper long; so only a selection of the figures is presented.

\subsection{Static tests results}

Fig. 7a shows the uplift capacity-displacement behaviour of both unreinforced and reinforced foundation beds (Test Series 1 and 2). For the reinforced tests, the belled pile is supported by a geocell layer over the bell, with a geocell height, $H_{t}$, of 25, 50, 75 and $100 \mathrm{~mm}$. In the case of the unreinforced bed and lightly reinforced bed $\left(H_{t}=25 \mathrm{~mm}\right)$, apparently the uplift strength failure (defined by the peak strength condition) took place at an outward displacement equal to $14 \mathrm{~mm}$. For the larger masses of reinforcement $\left(\mathrm{H}_{\mathrm{t}}=50,75\right.$, and $100 \mathrm{~mm}$ ), uplift capacity increases rapidly with displacement compared to unreinforced and lightly reinforced bed. In these cases, there is a reduction in the slope of the pullout-displacement curve beyond an outward displacement of 70-80 mm, corresponding to the fully unstable response of belled pile,. Overall, due to the reinforcing effects, a soil mass with geocell reinforcement had higher stiffness and strength than a soil mass without reinforcement. Also, at a given imposed stress level (any point before failure); the belled pile embedded in a reinforced bed had a significantly smaller outward displacement than a belled pile embedded in an unreinforced bed.

In order to show the performance due to geocell reinforcement, variation of uplift capacity with height of geocell, $H_{t}$, at different values of upward displacement, is shown in Fig. 7b. Generally, this figure shows that the increase in uplift capacity of the pile is higher at higher upward displacement, irrespective of the geocell mass above the bell of the pile. This indicates that the reinforcing efficacy increases with an increase in pile displacement (attributable to greater mobilization of tensile strain in the geocell layer and to the confinement 
1 provided by geocell's wall due to reinforcement). Uplift capacity increases steadily with an increase in the

2 height of the geocell layer, $\mathrm{H}_{\mathrm{t}}$ (attributed to the greater stiffness of the reinforced soil bed compared to that of

3 the unreinforced soil bed). Also, the rate of the enhancement in the uplift carrying capacity of the belled pile reduces with an increase in the height of the geocell layer $\left(\mathrm{H}_{\mathrm{t}}\right)$, so that no significant improvement in performance would be expected when the height of the geocell layer is more than $100 \mathrm{~mm}$. For example, at upward displacement of $6 \mathrm{~mm}$, the uplift capacities are about 64, 96, 115, 136, and $143 \mathrm{kPa}$ for unreinforced bed and geocell-reinforced bed with $H_{t}$ of $25,50,75$, and $100 \mathrm{~mm}$, respectively. This example shows that the performance improvement in uplift capacity for a variation of $H_{t}$ between 25 and $50 \mathrm{~mm}$ is substantially greater than that for a variation of $H_{t}$ between 75 and $100 \mathrm{~mm}$. This confirms that increasing the value of $H_{t}$ beyond $100 \mathrm{~mm}$ is not likely to deliver further substantial increase in uplift capacity.

This finding is similar to that reported by Ilamparuthi and Dickin (2001) and Ghosh and Bera (2010). Their investigations on the influence of geogrid reinforcement on the uplift performance of small scale belled piles showed that uplift resistance increases with the height of reinforcement zone.

\subsection{Repeated load tests results}

\subsubsection{The behaviour of the belled pile in unreinforced bed}

16 Fig. 8 illustrates the variation of applied repeated load with displacement (upward and downward 17 displacements) of the belled pile for the unreinforced bed (Test Series 3). This figure shows that at the first 18 cycle of compressive load, the downward displacement appears to be about $5 \mathrm{~mm}$, and thereafter at the first cycle of tensile load the displacement moves to the upward direction. After the initial load cycles, upward displacement of the belled pile increases significantly, so that excessive upward displacement, and consequently, unstable behaviour is observed, as the number of cycles increases (about 40-50 cycles). Furthermore, in this case, due to excessive upward displacement which starts after the first load cycle, significant heave of the fill surface (i.e., about $57 \mathrm{~mm}$ upward displacement, see Fig. 8) starts. This behaviour is attributable to rupture zones developing under the tensile cyclic loads locally in the region under and around the belled pile.

\subsubsection{The behaviour of the belled pile in reinforced bed}

27 The variation of applied repeated load with displacement of belled pile for the reinforced bed, the subject of Test Series 4, is shown in Fig. 9. The results are presented for four different heights of geocell reinforcement 
1 downward displacements of the belled pile in geocell reinforced bed is considerably decreased relative to the 2 unreinforced bed (Fig. 8) as a consequence of an increase in the height of the geocell reinforcement $\left(H_{t}\right)$ 3 above the bell. Fig. 9 shows that except to the unreinforced repeated load test (described in section 8.2.1, Fig.

4 8), the variation of belled pile displacement with the number of load cycles under loading and unloading 5 tends to become stable after a number of load cycles, particularly for the reinforced beds with the larger masses of reinforcement $\left(H_{t}=75\right.$ and $\left.100 \mathrm{~mm}\right)$. This stabilising response indicates that the early process of reorientation of particles inside the geocell pocket that causes local fill stiffening, ceases almost rapidly and the system then reaches the "plastic shakedown" condition. The condition was defined by Werkmeister et al. (2005) and Moghaddas Tafreshi and Dawson (2012) in which subsequent deformation is fully recovered in each cycle. In such case no yield condition is reached at conventional stress levels. Briefly saying, the results show that using the geocell reinforcement leads to stabilising behaviour, whereas no-reinforcement allows excessive displacement and unstable behaviour to develop. Likewise, this figure shows that the difference between maximum upward and downward displacements decreases with increase in the height of geocell. For example, the maximum upward displacement and the maximum downward displacement vary from about $-12.5 \mathrm{~mm}$ to $+10.5 \mathrm{~mm},-11.24 \mathrm{~mm}$ to $+9.88 \mathrm{~mm},-7.02 \mathrm{~mm}$ to $+7.72 \mathrm{~mm},-4.49 \mathrm{~mm}$ to $+4.65 \mathrm{~mm}$ for the geocell layer with height of $25,50,75$, and $100 \mathrm{~mm}$, respectively.

In order to investigate more clearly the beneficial effect of geocell reinforcement in decreasing the upward displacement and to investigate the effect of the number of load cycles, the variation of the upward displacement with the number of applied load repetitions as a consequence of the compressive and tensile repeated loading pattern (as illustrated in Fig. 6), is plotted in Fig. 10. The data are presented for unreinforced and geocell-reinforced sand beds with various heights of geocell $\left(H_{t}\right)$. The curves in Fig. 10 show the total upward displacement consisting both elastic and plastic displacements measured at the peak of each tensile load pulse. As can be seen, in the case of the lightly reinforced bed $\left(H_{t}=25\right.$ and $\left.50 \mathrm{~mm}\right)$, the upward displacement increases rapidly with an increase in the number of load cycles, and it would be expected to continue after $50^{\text {th }}$ load cycle. For the larger masses of reinforcement $\left(H_{t}=75\right.$ and $\left.100 \mathrm{~mm}\right)$, the displacement rate of the belled pile, after $20^{\text {th }}$ load cycle, is very small or insignificant, and geocell reinforcement leads to stabilising behaviour. Overall, Figs. 9-10 shows that with an increase in the height of the geocell, the rigidity of the reinforced system increases, or in another word, the maximum value of pile displacement decreases at any applied load cycles. This implies that increasing the amount of reinforcement mass over the bell of pile can control (lessen) the upward displacement of the pile, and provides greater stability for the pile, subjected 
1 to the cyclic compressive and tensile loads even under large number of load cycles. For example, at load

2 cycle of 50, the upward displacement values are about 11.12, 9.84, 5.62, and $3.08 \mathrm{~mm}$ for geocell layer with

3 height of $25,50,75$, and $100 \mathrm{~mm}$, respectively. The increase in performance is a consequence of the increased stiffness upon the increase of geocell's height.

A further observation is that, with increase in the height of the geocell layer, the rigidity of the reinforced system over the bell of the pile increases, which restrains the soil against heave, and thereby reducing heave of the fill surface. In the case of increasing the height of geocell to $100 \mathrm{~mm}$, the heave of the soil surface besides the pile shaft is approximately stopped and the geocell-soil composite system behaves like a slab, spreading the load far more effectively than the unreinforced soil system.

\subsubsection{The effect of the geocell layer beneath the base of the bell}

Fig. 11 presents the variation of applied repeated load with the displacement of the belled pile for the 12 geocell mattress with different heights $\left(H_{l}=25,50,75,100 \mathrm{~mm}\right)$ placed above the bell of the pile with an 13 additional geocell reinforcement layer, with the height of $H_{b}$ equal to $50 \mathrm{~mm}$, at its base (Test Series 5).

14 When comparing the total upward and downward displacements of the belled pile from Fig. 9 and Fig. 11 15 (displacement of belled pile embedded in geocell reinforced bed with and without a geocell layer at the bell 16 base), it is clear that the performance of reinforcement in decreasing upward and downward displacements are significantly improved due to the additional geocell layer. On the other hand, the difference between maximum upward and downward displacements decreases for the reinforced bed with an additional layer of geocell at the base, as compared with the geocell reinforced bed system without an additional geocell layer. The improvement could be attributed to the fact that the bell pile without a geocell layer at the base, experiences large settlements under the compressive loads, results a disturbed soil zone around the pile, and therefore decreases the uplift resistance of system, and consequently increases the upward displacement during the compressive and tensile load cycles. On the other hand, an additional geocell layer contributes to the performance improvement by resisting the downward movement of the pile and preventing the disturbance of the soil around the pile to as little amount as possible, during repeated compressive and tensile loads. 
In order to have a direct comparison of the results for the geocell reinforced bed with an additional

2 geocell layer and without an additional geocell layer, from the viewpoint of decreasing the displacements of

3 the belled pile, the variation of downward and upward displacements of the belled pile versus the height of geocell layer above the bell of pile are shown in Fig. 12, at load cycles of 10, 30, and $50(N=10,30,50)$. Solid lines and dashed lines show the variation of displacement with and without an additional layer, respectively.

From the results presented in Fig. 12, it is seen clearly that for all load cycles, the geocell reinforced bed system with an additional geocell layer at the base, has a smaller downward displacement (Fig. 12a) and a smaller upward displacement (Fig. 12b) as compared with the geocell reinforced bed system without an additional geocell layer. For example, the upward displacements of the pile at load cycle of 50, recorded for reinforced bed with and without additional geocell layer, were 10.01 and $12.50 \mathrm{~mm} ; 8.30$ and $11.24 \mathrm{~mm}$; 4.05 and $7.02 \mathrm{~mm}$; 2.18 and $4.49 \mathrm{~mm}$; for the geocell heights of $25 \mathrm{~mm}, 50 \mathrm{~mm}, 75 \mathrm{~mm}$, and $100 \mathrm{~mm}$, respectively. Generally, this comparison implies that the geocell reinforced system with an additional geocell layer beneath the bell of the pile behaves as a much stiffer system and it is consistently more efficient, compared to the same geocell reinforced system without an additional layer, in reducing the upward and downward displacements.

The behaviour of a belled pile contained within geocell reinforcement layer is complex, involving interaction between the geocell pockets, the surrounding soil, the shaft pile, and the bell of the pile. Obviously, the tests conducted in this study, are not adequate for a complete understanding of the mechanism and interaction of the belled pile in reinforced bed system. However, the test results may provide an indication of the advantages of using geocell reinforcement in increasing the uplift capacity and decreasing the upward and downward displacements of the belled pile. In general, the advantages of the geocell reinforced system against the unreinforced system in increasing the performance of the belled pile could be attributed to a combination of the following reasons:

- When the cells of geocell are filled with soil, the moment of inertia, and hence shear and bending rigidity of the geocell layer above or beneath the bell of the pile, become significantly greater than soil alone (unreinforced soil), 
- The soil in the pockets forms a better composite material and behaves as a stiffer bed that redistributes stress over a wider area causing an increase in the uplift capacity and consequently, a decrease in the upward and downward displacements of the belled pile system,

- During uplift, the dilation of soil particles within the cell pockets of geocell tends to force the cell wall material to expand. The geocell resistance to this expansion results in increased confinement, so that the cell walls of geocell reinforcement keep the encapsulated soil from being displaced, by confining the material through hoop action of a cell, thereby increasing the shear strength of the composite system,

- The additional layer of geocell at the base of the belled pile acts like a large mat that spreads the applied load over an extended area, instead of directly at the point of contact, and provides a composite slab with high flexural stiffness and load support capabilities within the geocell reinforcement. This consequently leads to an improvement in the overall performance regarding the bearing pressure of foundation bed beneath the bell of the pile (Moghaddas Tafreshi and Dawson, 2010a,b), so that it prevents disturbing the soil around the pile shaft or minimizes it during repeated compressive and tensile loads, and reduces the upward and downward displacements of the pile.

\section{Limitation and applicability}

The results presented herein provide encouragement for the application of geocell reinforcement to protect the belled pile against the uplift forces. However, it should be noted that the presented results are based on the tests conducted on a small model of belled pile, at unit gravity, for only one type of geocell, one pocket size of geocell, one type of soil, one diameter and one length of shaft pile, and one diameter of bell which were used by the authors. Thus, full application should only be made after considering the above limitations and trying a large size model to confirm the results of this study.

Qualitatively, this study provided insight into the basic mechanism responsible for the behaviour of belled pile under repeated compressive and tensile loads supported by geocell reinforced soil. In studies of largescale and small-scale tests on behaviour of granular layers with geogrid reinforcement, Adams and Collin (1997) and Milligan et al. (1986) showed that the general mechanisms and behaviours observed in the small model tests could be reproduced at large-scale. For these reasons, the general trends observed in this study are expected to be similar to general trends in a full-size test. Nevertheless, it would be wise, in future tests, to assess larger scale models of belled piles at various conditions. For example, different soils, different pile 
1 shafts (in diameter and length), and different characteristics (especially stiffness) and pocket size of the

2 geocell should be studied to validate the present findings and to determine the existence of a scale effect.

3 However, when conducting model tests, the scale effect prevents direct comparison with full-scale.

4 Therefore the authors undertook a preliminary dimensional analysis, as employed by several researchers in

5 geotechnical engineering (e.g., Love 1984; El-Emam and Bathurst, 2007; Sireesh et al., 2009), to assess the

6 effect of scaling by a factor of $\lambda$ (the ratio of diameter of prototype bell of pile to diameter of model bell of

7 pile). Loading and deflection parameters, the pocket size of the geocell, shear modulus of soil, unit weight of

8 soil, angle of internal shearing resistance of the soil and stiffness of geotextile used were all considered as

9 relevant parameters for this analysis. Although the details of dimensional analysis is not reported, here, it was

10 deduced that the reinforcement used at full-scale requires a stiffness $\lambda^{2}$ times that of reinforcement used in the

11 model tests, and a soil shear modulus increased by $\lambda$, therefore, full-scale performance improvements to the

12 extent seen in the model tests would necessitate fabrication from geocells formed of geosynthetic material

13 that is $\lambda^{2}$ times stiffer. As the strength and stiffness of the geocell joints are equal or greater than the values of

14 these properties for the cell wall geosynthetic (Treff, 2011), the same increase in bond characteristics will

15 probably be needed, too. Given the relatively low stiffness of soil used in the model tests, the increased soil

16 stiffness required for dimensional similitude should be relatively easily attained in practice.

17 Likewise, the insight into the basic mechanism, that establishes the pullout resistance and displacement

18 response of the belled pile in geocell reinforced soil, should be helpful in designing larger tests, for further

19 research leading to an increased understanding of the application of soil reinforcement to uplift capacity

20 problems, or in simulation through numerical models.

\section{11. Summary and conclusions}

In this study, a series of laboratory model load tests under a combination of static and repeated compressive and tensile loads has been carried out with a belled pile supported on reinforced and unreinforced geocell soil beds. The test results were used to assess and understand the potential benefits of reinforcing sand with geocells, in terms of decreased upward and downward displacements of the belled pile compared to a belled pile in unreinforced beds. The various parameters studied in this testing program include the geocell height above the bell of pile, and an additional layer of geocell at the base of the belled pile model. Based on the results obtained from the present study, the following conclusions can be derived: 
1 (1) For the belled pile in unreinforced bed, during few first cycles of repeated loads, the upward displacement of the belled pile increases significantly, so that excessive upward displacement and, consequently, unstable behaviour and significant heave of the fill surface is observed.

(2) The geocell reinforced bed changes the behaviour of belled pile from unstable response condition due to excessive pile displacement (in unreinforced bed), to steady response condition.

6 (3) With increase in the height of geocell layer above the bell of the pile, the performance improvement in decreasing the upward displacement of the pile increases. Using the adequate mass of geocell (adequate height of geocell) causes a remarkable decrease in the upward displacement of the pile and heave of the soil surface due to geocell reinforcement action, so that with geocell height of 75 and $100 \mathrm{~mm}\left(H_{t}=75\right.$ and $100 \mathrm{~mm})$, the pile displacements under repeated loads tend to become stable after a number of load cycles.

(4) The rate of reduction in upward displacement of the belled pile in reinforced bed was reduced with an increase in the number of load cycles, particularly for the larger mass of geocell.

(5) An additional layer of geocell at the base of the belled pile appears to act accompanied with the soil, and to behave as a slab that redistributes the compressive loads over a larger area, leading to a reduction in downward displacement, and consequently a reduction in disturbing the soil around the pile shaft, and delivering a more progressive reduction in upward and downward displacements of the pile.

(6) This study suggests that, geocell reinforced bed with an additional geocell layer at the base of belled pile would provide a practical alternative, and beneficial solution to increase the uplift capacity of belled pile under compressive and tensile loads.

(7) The deflection results suggest that full-scale anchor piles fabricated in the manner studied in this paper would need tensioning to provide a constant tension capacity and to take up any initial low stiffness response. In static use creep might be an issue (especially if polymeric geocell material was to be employed as herein) and this aspect needs further study. Under repeated loads, as for example imposed by tall structures on tension foundations installed to prevent overturning due to periodic wind loading, there would probably need to be some re-tensioning early in the life of the foundation if deflections were to be kept small.

(8) A simple dimensional analysis of the model-scale results suggests that full-scale application of the type of arrangements described in this paper is likely to deliver the same type of behaviour and benefits described herein. For full-scale application, the prototype geocell, both joint and geotextile (and other 
strip material to make geocell), should have a stiffness of $\lambda^{2}$ times the strength and stiffness of the geocell used in the present model tests, however to realize full benefit. A geocell meeting this target would thus require relatively stiff geotextile products. The soil material should have a modulus $\lambda$ times higher than that of the sand used in the model tests - a factor that is well within the range of likely stiffnesses ratio between such materials.

6 (9) Clearly, this is a preliminary study and full application should only be made after considering the limitations and trying a large size model to confirm the results of this study.

\section{Acknowledgment}

9 The authors would like to thank DuPont de Nemours, Luxembourg, and their UK agents, and TDP 10 Limited, for the geocell and planar reinforcement support with the testing program. In addition, the authors 11 would like to offer their sincere appreciation to the UK agents, TDP Limited, for their technical advice and 12 insight.

\section{References}

14 Adams, M.T., Collin, J.G., 1997. Large model spread footing load tests on geosynthetic reinforced soil foundations. 15 Journal of Geotechnical and Geoenvironmental Engineering, ASCE 123 (1), 66-72.

16 Ahmadi, H., Hajialilue-Bonab, M., 2012. Experimental and analytical investigations on bearing capacity of strip footing 17 in reinforced sand backfills and flexible retaining wall. Acta Geotech 7 (4), 357-373.

18 American Society for Testing and Materials, 2003. Standard Practice for Classification of Soils for Eng. Purposes, Unified Soil Classification System. ASTM International; D 2478.

American Society for Testing and Materials, 2007. Standard Test Method for Density and Unit Weight of Soil in Place by the Sand-Cone Method. ASTM International; D1556.

Choudhary, A.K., Jha, J.N., Gill, K.S., 2010. Laboratory investigation of bearing capacity behaviour of strip footing on reinforced. Geotextiles and Geomembranes 28 (4), 393-402.

Consoli, N.C., Ruver, C.A., Girardello, V., Festugato, L.. Thome, A., 2012. Effect of polypropylene fibers on the uplift behavior of model footings embedded in sand. Geosynthetics International, 19 (1), 79-84. underlain by soft clay. Geotextiles and Geomembranes, 21 (4), 197-219 
1 Deskmukh, V.B., Dewaikar, D.M., Deepankar Choudhury., 2010. Computations of uplift capacity of pile anchors in cohesionless soil. Acta Geotechnica, 5 (2), 87 - 94 .

3 Dickin, E.A., Leung, C.F., 1990. Performance of piles with enlarged bases subjected to uplift forces. Canadian Geotechnical J., 27(5):546-556.

5 Consoli, N.C., Ruver, C.A., Girardello, V., Festugato, L.. Thome, A., 2012. Effect of polypropylene fibers on the uplift behavior of model footings embedded in sand. Geosynthetics International, 19 (1), 79-84.

El-Emam, M., Bathurst, R.J., 2007. Influence of reinforcement parameters on the seismic response reduced-scale reinforced soil retaining walls. Geotextiles and Geomembranes 25 (3), 33-49.

9 El Sawwaf, M.A., Nazir, A., 2006. The effect of soil reinforcement on pullout resistance of an existing vertical anchor plate in sand. Computers and Geotechnics, 33 (3), 167-176.

11 El Sawwaf, M.A., Nazir, A., 2012. Behavior of Eccentrically Loaded Small-Scale Ring Footings Resting on Reinforced Layered Soil. Journal of Geotechnical and Geoenvironmental Engineering 137, No. (3), 376-384.

13 Ghosh, A., Bera, A.K., 2010. Effect of Geotextile Ties on Uplift Capacity of Anchors Embedded in Sand. Geotech Geol Eng., 28 (5), 567-577.

Hanna, A.M., Ghaly, A.M., 1994. Ultimate pull out resistance of groups of vertical anchors. Canadian Geotechnical J., 31(5), 673-682.

Honda, T., Hirai, Y., Sato, E., 2011. Uplift capacity of belled and multi-belled piles in dense sand. Soils and Foundations, $51(3), 483-496$.

Horpibulsuk, S., Niramitkorburee, A., 2010. Pullout resistance of bearing reinforcement embedded in sand. Soils and Foundations, 50 (2), 215-228.

Ilamparuthi, K., Dickin, E.A., 2001. The influence of soil reinforcement on the uplift behaviour of belled piles embedded in sand. Geotextiles and Geomembranes, 19 (1), 1-22.

Ilamparuthi, K., Dickin, E.A., 2001. Predictions of the uplift response of model belled piles in geogrid-cell-reinforced sand. Geotextiles and Geomembranes, 19 (2), 89-109.

Ilamparuthi, K., Dickin, E,A., Muthukrisnaiah, K., 2002. Experimental investigation of the uplift behaviour of circular plat anchors embedded in sand. Canadian Geotechnical J., 39 (3), 648-664.

Kouzer, M.K., Jyant, K., 2009. Vertical uplift capacity of two interfering horizontal anchors in sand using an upper bound limit analysis. Computers and Geotechnics, 36 (6), 1084-1089. 
1 Leshchinsky, B., Ling, H. I., 2013. Numerical modeling of behavior of railway ballasted structure with geocell confinement. Geotextiles and Geomembranes, 36 (1), 33-43.

3 Ling, H.I., Liu, H., 2009. Deformation analysis of reinforced soil retaining walls—simplistic versus sophisticated finite element analyses. Acta Geotech 4 (3), 203-213.

5 Love, J. P., 1984. Model testing of geogrids in unpaved roads,. PhD thesis. Univ. of Oxford, Oxford, U.K.

6 Lovisa, J., Kumar Shukla, S., Sivakugan, N., 2010. Behaviour of prestressed geotextile-reinforced sand bed supporting a loaded circular footing. Geotextiles and Geomembranes, 28 (1), 23-32.

Merifield. R.S., Sloan, S.W., 2006. The ultimate pullout capacity of anchors in frictional soils. Canadian Geotechnical J., 43(8): 852-868.

10 Madhavi Latha, G., Somwanshi, A., 2009. Bearing capacity of square footings on geosynthetic reinforced sand. Geotextiles and Geomembranes 27 (4), 281-294.

12 Milligan, G.W.E., Fannin, R.J., Farrar, D.M., 1986. Model and full-scale tests of granular layers reinforced with a 13 geogrid. In: Proceedings of Third International Conference on Geotextiles, Vol. 1. Vienna, pp. 61-66.

14 Moghaddas Tafreshi, S.N., Dawson, A.R., 2010a. Comparison of bearing capacity of a strip footing on sand with geocell and with planar forms of geotextile reinforcement. Geotextiles and Geomembranes 28 (1), $72-84$.

Moghaddas Tafreshi, S.N., Dawson, A.R., 2010b. Behaviour of footings on reinforced sand subjected to repeated loading - Comparing use of 3D and planar geotextile. Geotextiles and Geomembranes 28 (5), 434-447.

Moghaddas Tafreshi, S.N., Khalaj, O., Halvaee, M., 2011. Experimental study of a shallow strip footing on geogridreinforced sand bed above a void. Geosynthetics International, Thomas Telford , 18 (4), 178 -195. geocell-reinforced sand. Geotextiles and Geomembranes 32, 55-68.

Sakai T, Tanaka, T., 2007. Experimental and numerical study of uplift behavior of shallow circular anchor in two-layered sand. J Geotech Geoenviron Eng., 133 (4), 469-477.

24 Sireesh, S., Sitharam, T.G., Dash, S.K., 2009. Bearing capacity of circular footing on geocell-sand mattress overlying clay bed with void. Geotextiles and Geomembranes 27 (2), 89-98.

Song, Z., Hu, Y., Randolph, M.F., 2008. Numerical simulation of vertical pullout of plate anchors in clay. J Geotech Geoenviron Eng., ASCE, 134 (6), 866-887. 
1 Tanyu, B. F., Aydilek, A. H., Lau, A. W., Edil, T. B., Benson, C. H., 2013. Laboratory Evaluation of Geocell-Reinforced 2 ravel Subbase Over Poor Subgrades. Geosynthetics International, 20 (2), 46-71.

3 Treff, A., 2011. Private Communication with Albert Treff of DuPont de Nemours, Luxembourg.

4 Werkmeister, S., Dawson, A. R., Wellner, F., 2005. Permanent Deformation Behaviour of Granular Materials, Int. Jnl. 5 Road Materials and Pavement Design, 6, 31-51.

6 Yang, X., Han, J., Leshchinsky, D., Parsons, R.L., 2013. A three-dimensional mechanistic-empirical model for geocellreinforced unpaved roads. Acta Geotechnica, 8 (2), 201-213.

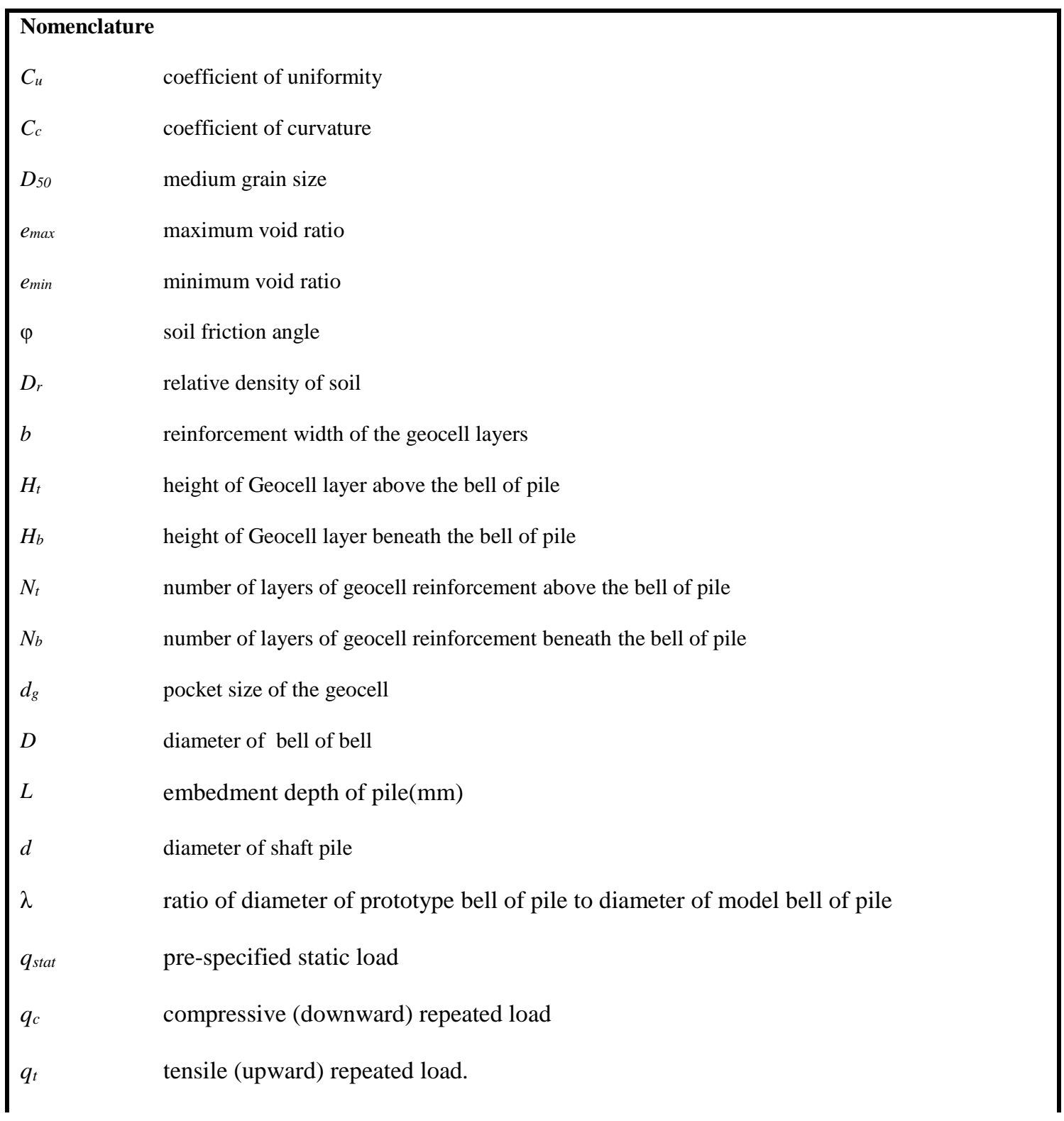




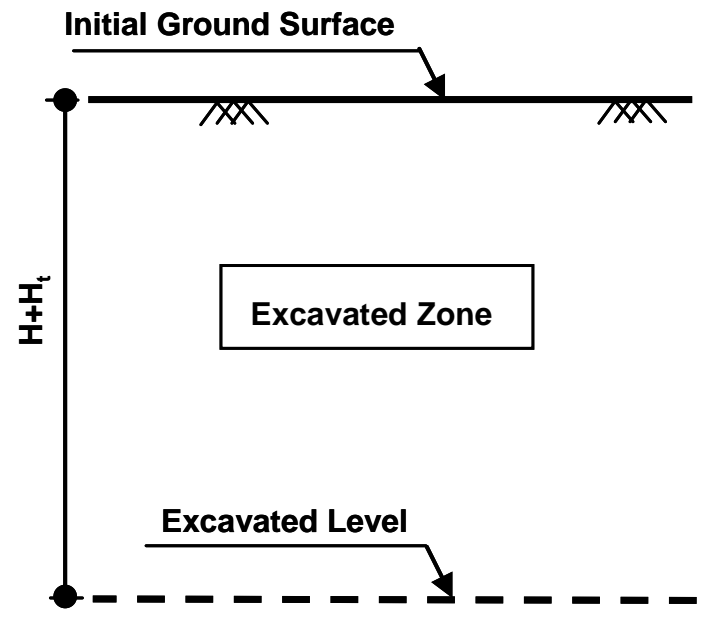

(a)

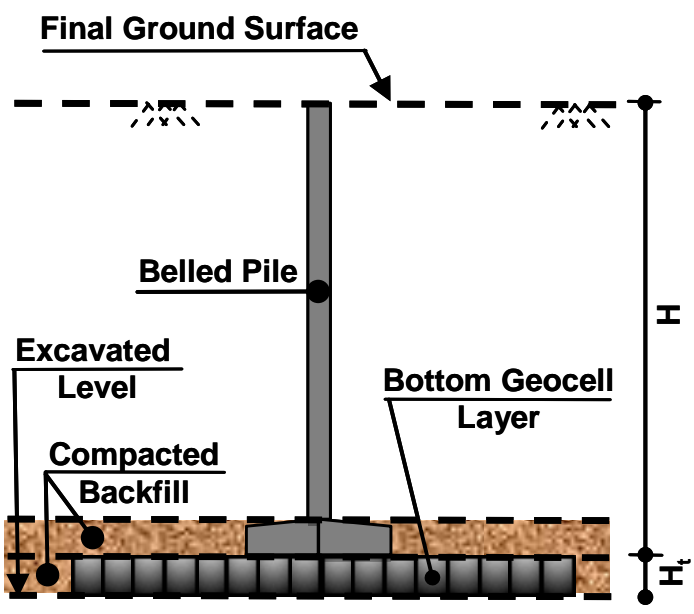

(c)
Final Ground Surface

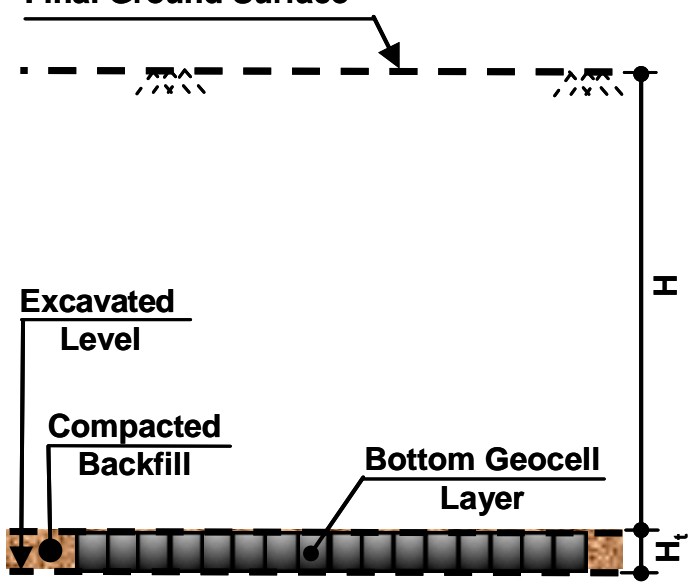

(b)

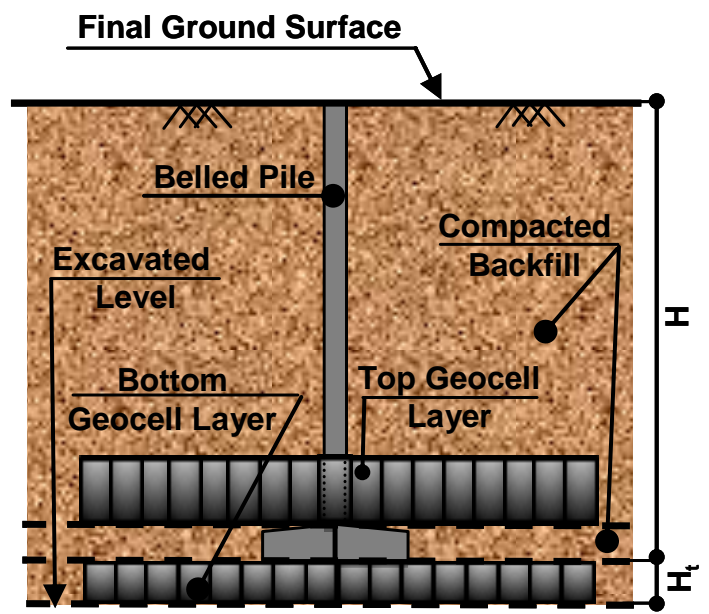

(d)

Fig. 1. Sketch of belled pile installation in geocell-reinforced backfill (a) excavation in backfill, (b) installation of the bottom geocell layer and compaction soil backfill, (c) installation of the precast belled pile, (d) placement of the top geocell layer and compaction soil backfill. 


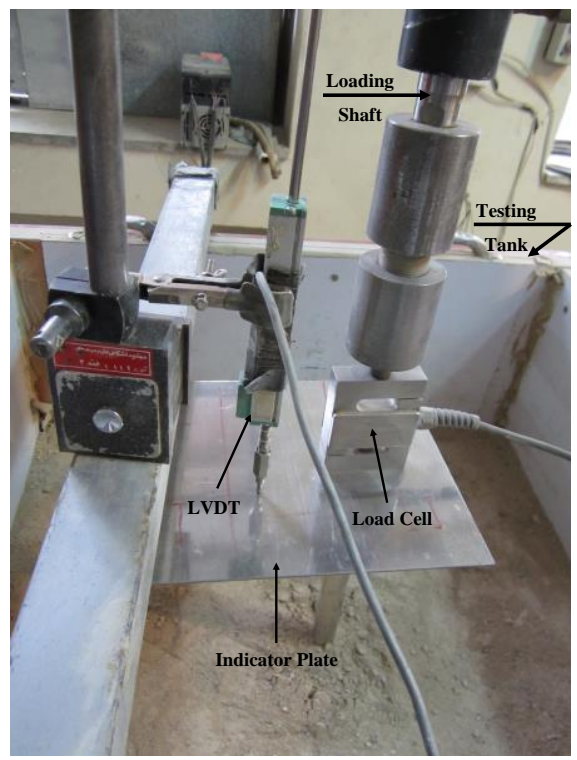

Fig. 2. General view of the physical test setup, including testing tank, loading system and data measurement system.

1

2

3

4

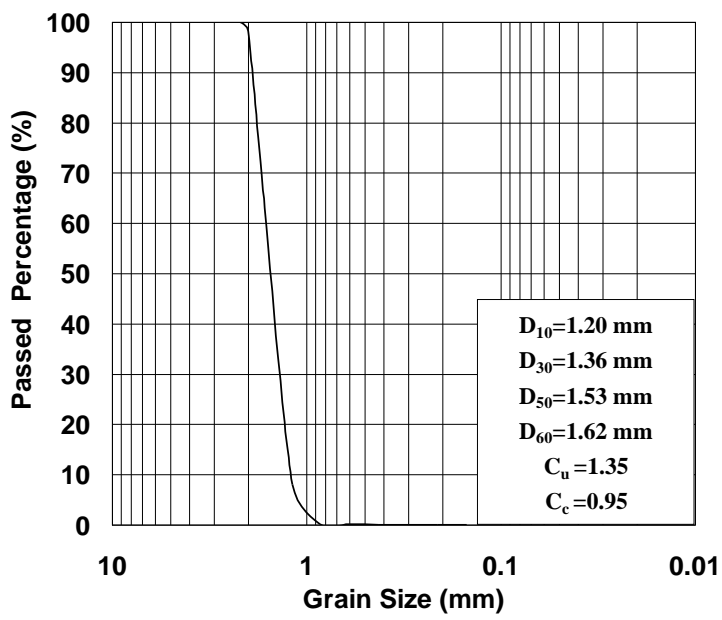

Fig. 3. Particle size distribution curve. 


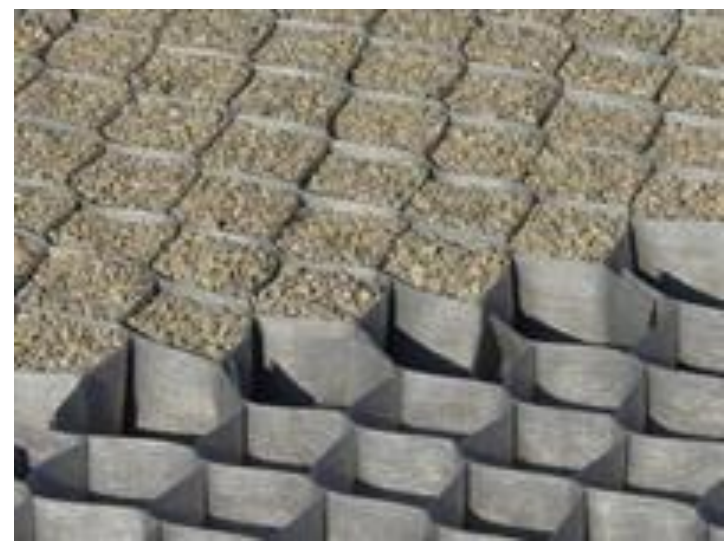

Fig. 4. Non-perforated flexible geocell (TDP Limited) used in this research.

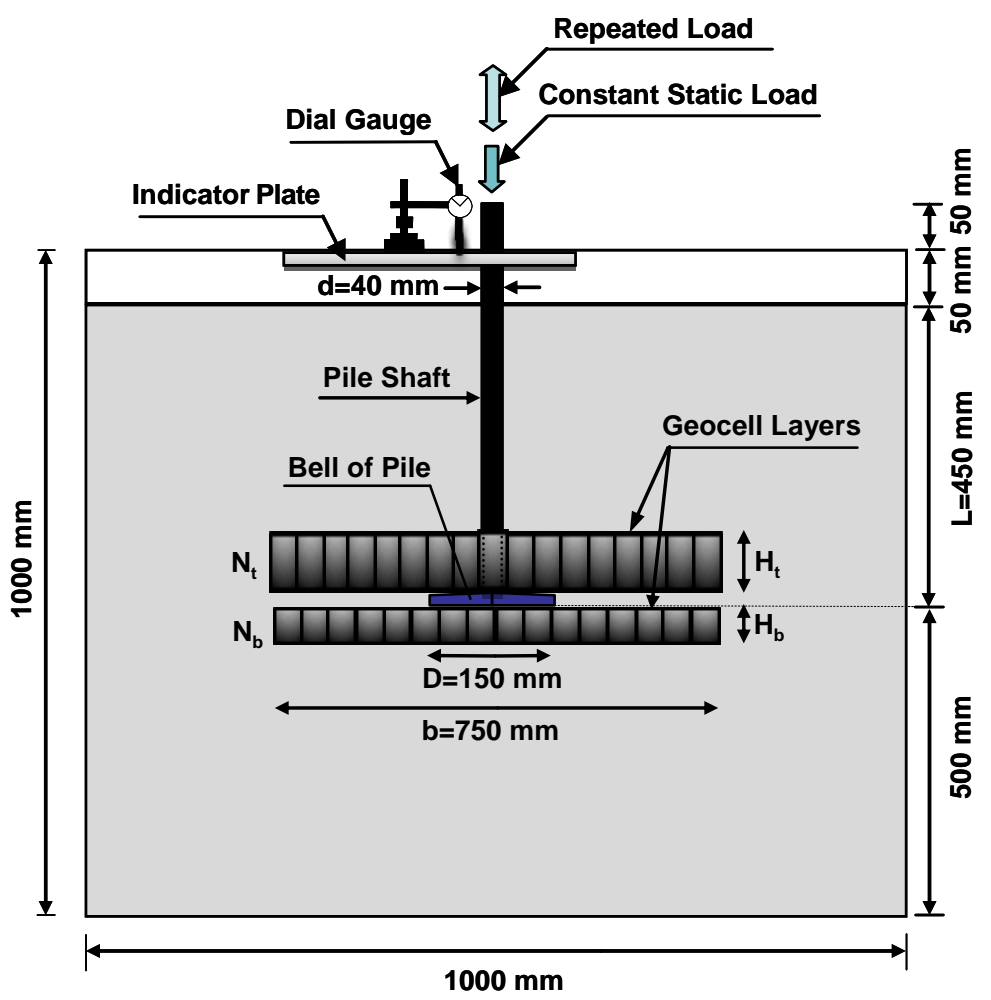

Fig. 5. Geometry of the geocell reinforced bed and belled pile (not in scale). 


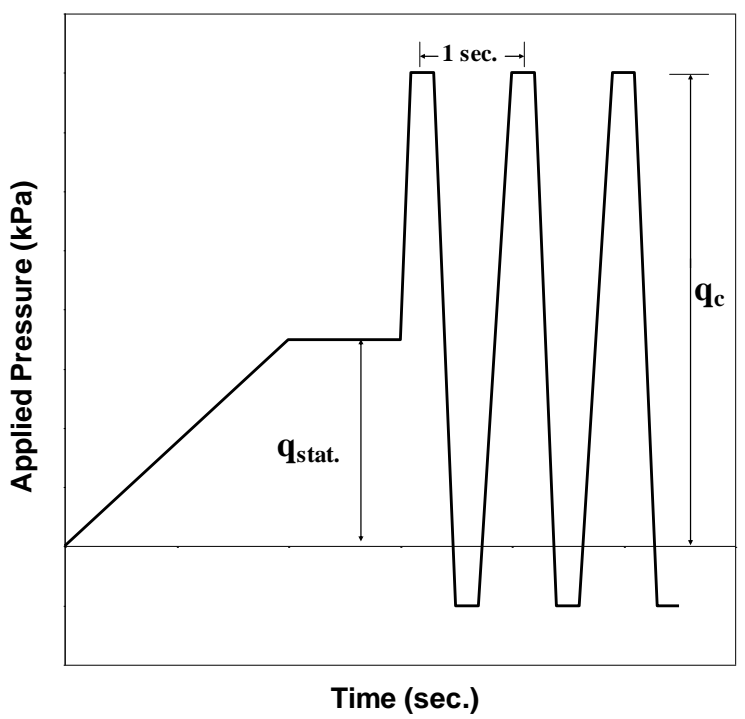

Fig. 6. Typical time history of initial static and compressive/tensile repeated load on belled pile.

1

2

3

4

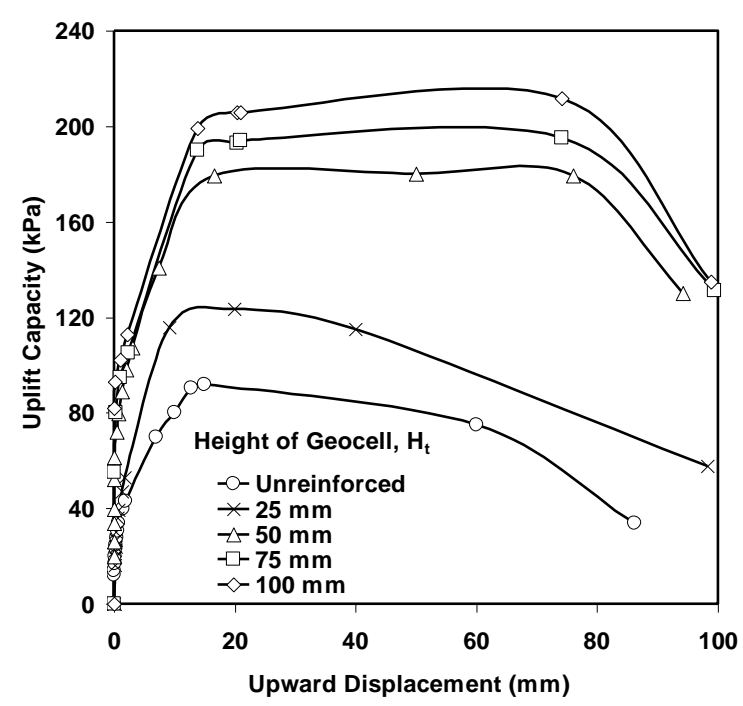

(a)

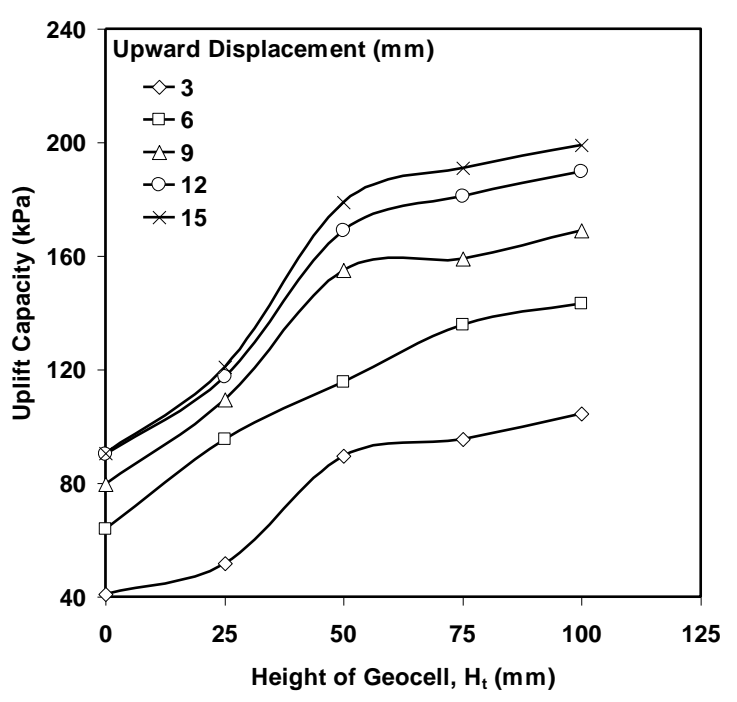

(b)

Fig. 7. Variation of uplift capacity with (a) upward displacement for different heights of geocell, (b) height of geocell, $H_{t}$ at different values of upward displacement. 


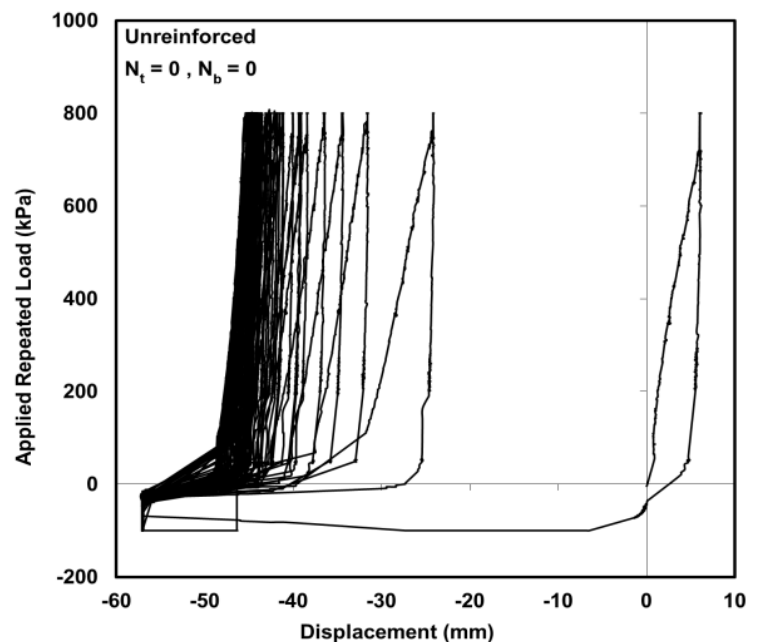

Fig. 8. Variation of applied repeated load with displacement of belled pile for the unreinforced bed.

1

2

3

4

5

6

7

8

9

10

11

12

13 


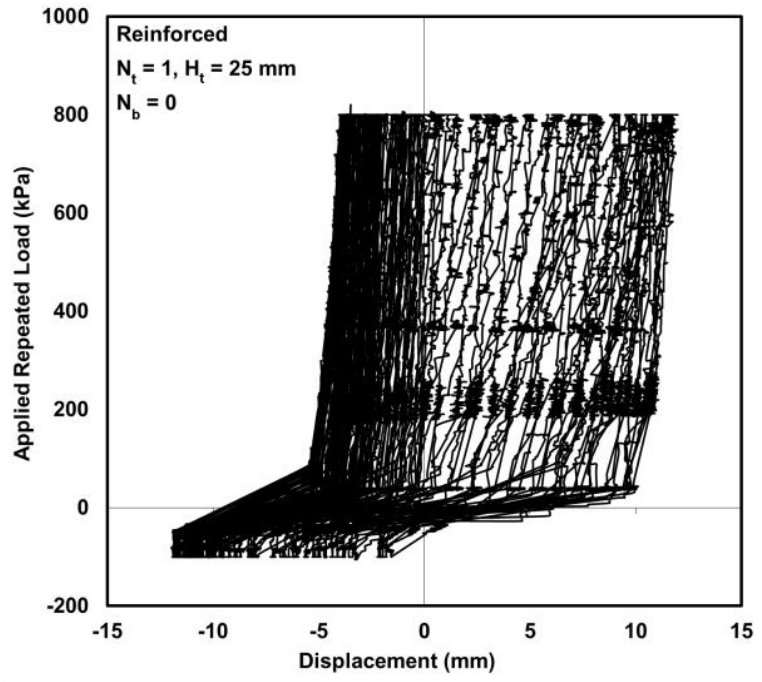

(a)

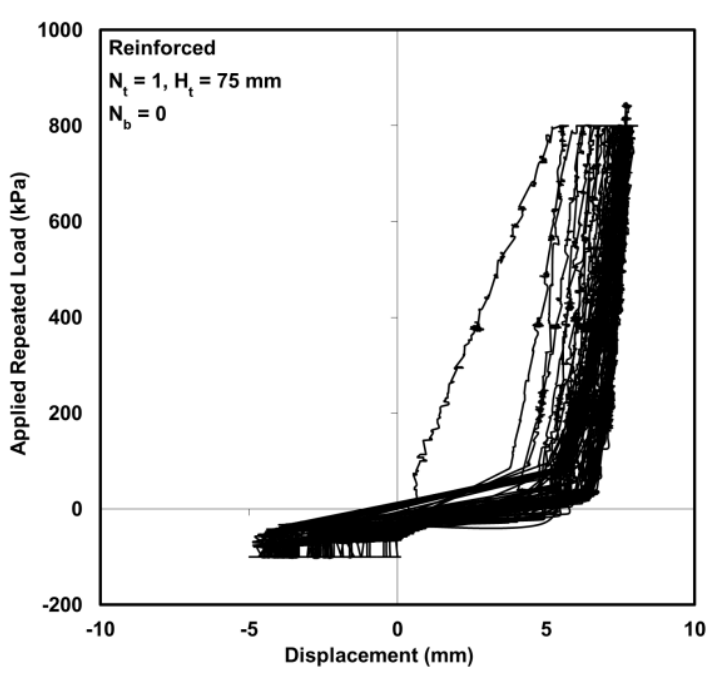

(c)

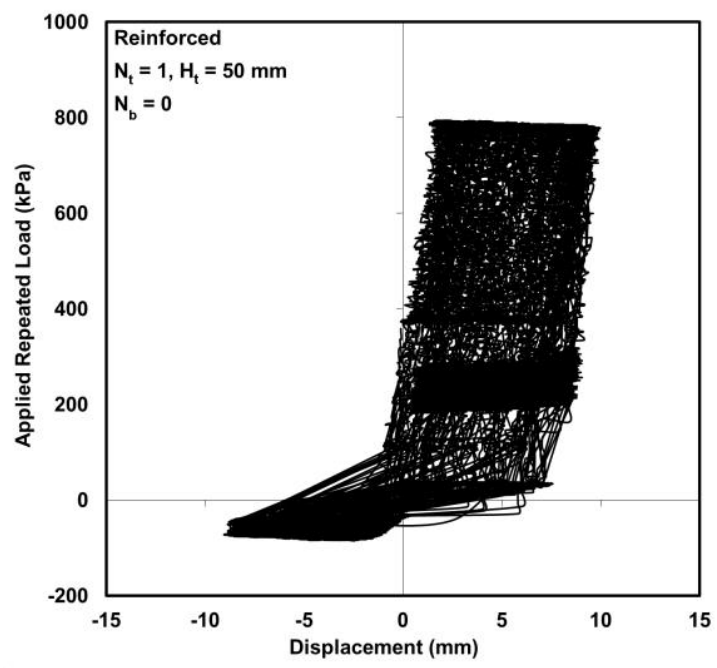

(b)

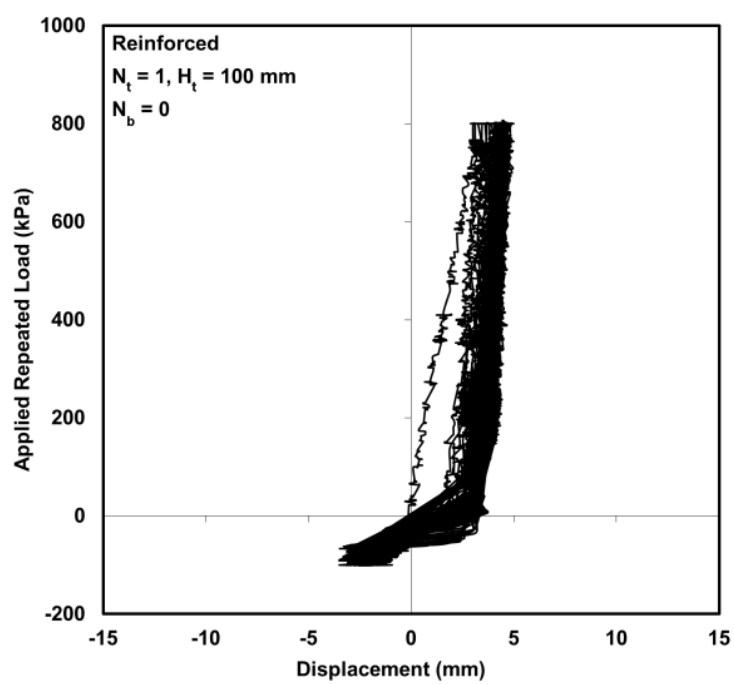

(d)

Fig. 9. Variation of applied repeated load with displacement of belled pile for four different heights of geocell layer above the bell of the pile, (a) $H_{t}=25 \mathrm{~mm}$, (b) $H_{t}=50 \mathrm{~mm}$, (c) $H_{t}=75 \mathrm{~mm}$, (d) $H_{t}=100 \mathrm{~mm}$. 


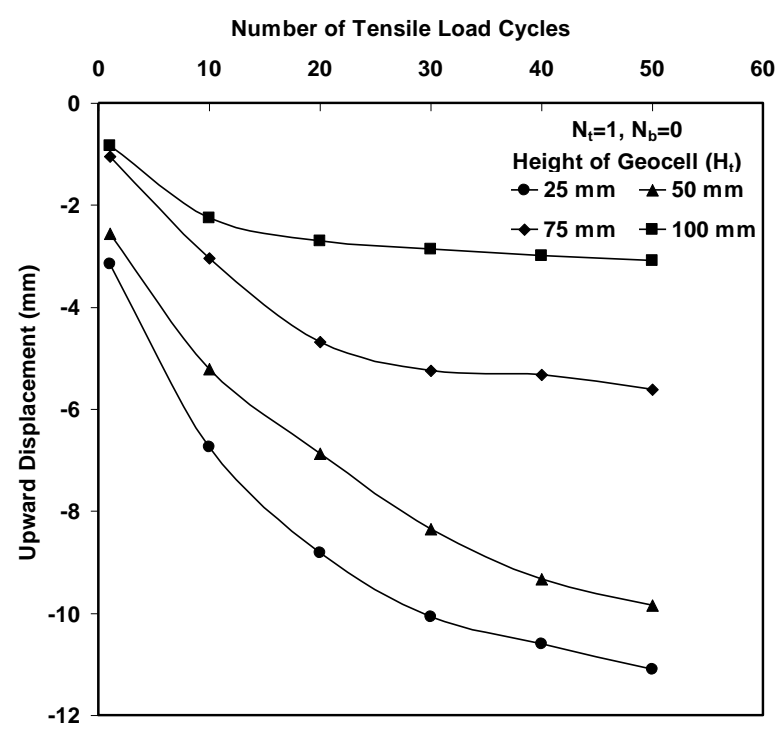

Fig. 10. Variation of the upward displacement of the belled pile with number of applied load repetitions for the geocellreinforced beds with various heights of geocell.

3

4

5

6

7

8

9

10

11

12

13

14

15

16

17

18 


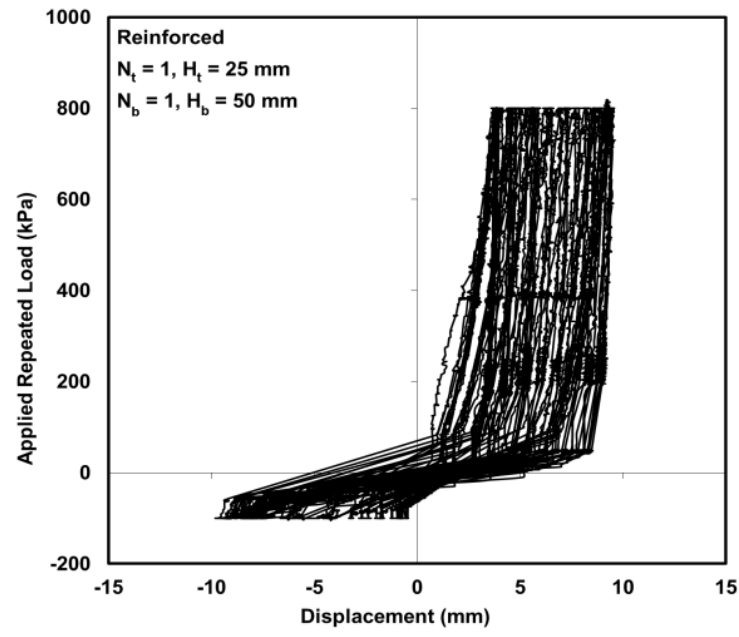

(a)

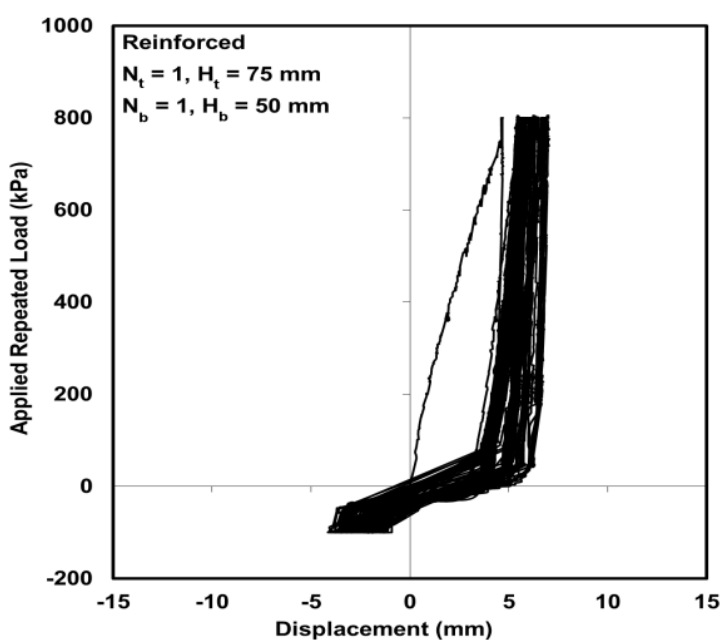

(c)

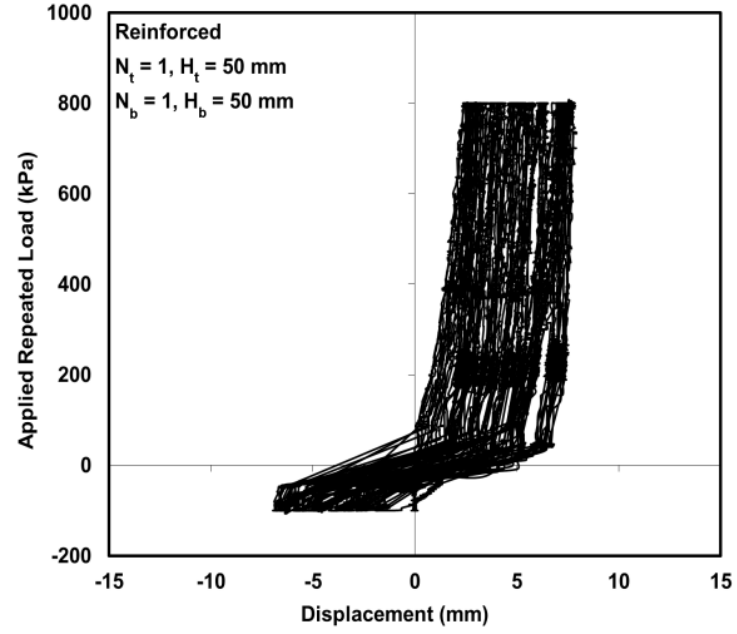

(b)

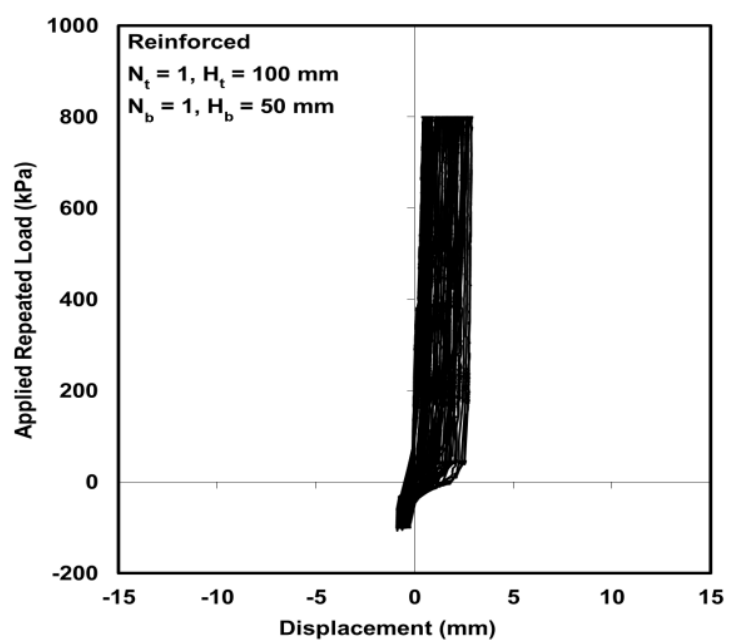

(d)

Fig. 11. Variation of applied repeated load with displacement of the belled pile for different heights of geocell layer above the bell of pile with an additional geocell layer beneath the bell of pile, (a) $H_{t}=25 \mathrm{~mm}$, (b) $H_{t}=50 \mathrm{~mm}$, (c) $H_{t}=75$ $\mathrm{mm}$, (d) $H_{t}=100 \mathrm{~mm}$. 
2

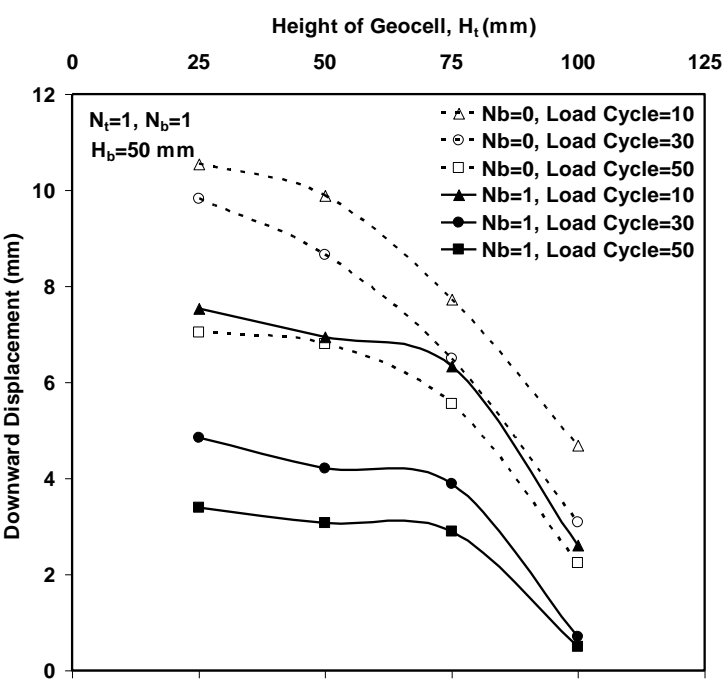

(a)

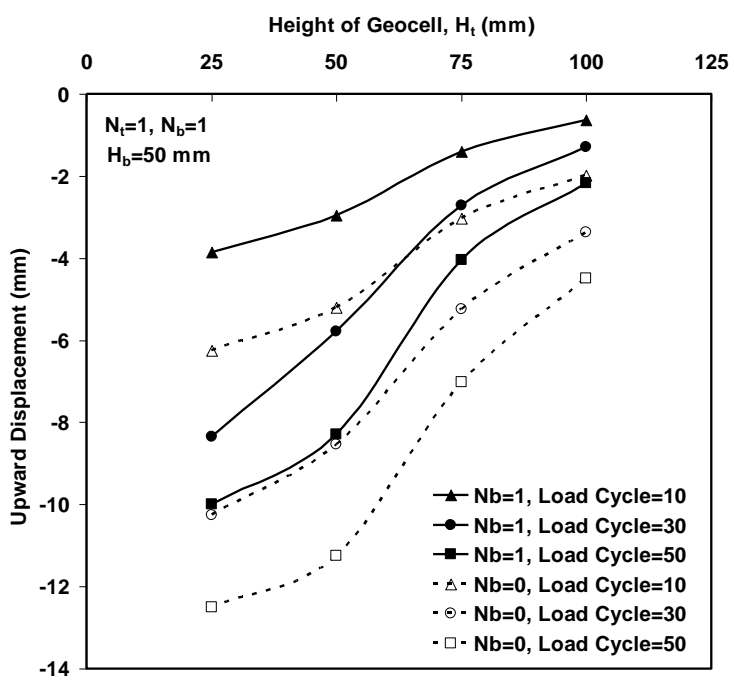

(b)

Fig. 12. Variation of the displacement of the belled pile with height of geocell above the bell of pile with and without the geocell layer at the base, (a) downward displacement; (b) upward displacement.

Table 1. Physical properties of soil.

\begin{tabular}{ll}
\hline \multicolumn{1}{c}{ Description } & Value \\
\hline Coefficient of uniformity, $C_{u}$ & 1.35 \\
Coefficient of curvature, $C_{c}$ & 0.95 \\
Effective grain size, $D_{10}(\mathrm{~mm})$ & 1.2 \\
$D_{30}(\mathrm{~mm})$ & 1.36 \\
Medium grain size, $D_{50}(\mathrm{~mm})$ & 1.53 \\
$D_{60}(\mathrm{~mm})$ & 1.62 \\
Maximum void ratio, $e_{\max }$ & 0.82 \\
Minimum void ratio, $e_{\min }$ & 0.54 \\
Moisture content $(\%)$ & 0 \\
Specific gravity, $G_{s}$ & 2.68 \\
Friction angle, $\phi($ degree$)$ at $84 \%$ & 38.5 \\
relative density & \\
\hline
\end{tabular}


Table 2

The engineering properties of the geotextile used in the tests (manufacturer's data).

\begin{tabular}{ll}
\hline Description & Value \\
\hline Type of geotextile & Non-woven \\
Weight per area $\left(\mathrm{gr} / \mathrm{m}^{2}\right)$ & 68 \\
Thickness under $2 \mathrm{kN} / \mathrm{m}^{2}(\mathrm{~mm})$ & 0.35 \\
Thickness under $200 \mathrm{kN} / \mathrm{m}^{2}(\mathrm{~mm})$ & 0.28 \\
Tensile strength $(\mathrm{kN} / \mathrm{m})$ & 3.4 \\
Strength at $5 \%(\mathrm{kN} / \mathrm{m})$ & 1.8 \\
Effective opening size $(\mathrm{mm})$ & 0.04 \\
\hline
\end{tabular}

3

4 Table 3

5 Scheme of the static and repeated load tests for the belled pile embedded in unreinforced and multi-layered geocell

6 reinforced soil.

\begin{tabular}{|c|c|c|c|c|c|c|}
\hline \multirow[t]{2}{*}{$\begin{array}{l}\text { Test } \\
\text { Series }\end{array}$} & \multirow[t]{2}{*}{$\begin{array}{l}\text { Type of } \\
\text { test }\end{array}$} & \multicolumn{2}{|c|}{ Geocell layers over the bell of pile } & \multicolumn{2}{|c|}{$\begin{array}{l}\text { Geocell layer beneath the bell of } \\
\text { pile }\end{array}$} & \multirow[t]{2}{*}{ No. of Tests } \\
\hline & & $\overline{\mathrm{H}_{\mathrm{t}}(\mathrm{mm})}$ & $\overline{N_{t}}$ & $\overline{\mathrm{H}_{\mathrm{b}}(\mathrm{mm})}$ & $\overline{\mathrm{N}} \mathrm{b}$ & \\
\hline 1 & Static & \multicolumn{4}{|l|}{ Unreinforced } & $1+1 *$ \\
\hline 2 & Static & $25,50,75,100$ & 1 & ---- & ---- & $4+2 *$ \\
\hline 3 & \multirow[t]{2}{*}{ Repeated } & \multicolumn{4}{|l|}{ Unreinforced } & $1+1 *$ \\
\hline 4 & & $25,50,75,100$ & 1 & ----- & ----- & $4+3 *$ \\
\hline 5 & Repeated & $25,50,75,100$ & 1 & 50 & 1 & $4+3 *$ \\
\hline
\end{tabular}

$7 \quad$ *Indicates duplicate tests performed to verify the repeatability of the test data

8 